4. Gorish, A. V., Dudkevich, V. P., Kupriyanov, M. F. et. al. (1999) P'ezoelektricheskoe priborostroenie. Vol. 1. Fizika segnetoelektricheskoi keramiki. Moscow: Izdat. predpr. red. zhur. «Radiotekhnika», 368.

5. Osadchii, E. P., Tikhonov, A. I., Karpov, V. I., Zhuchkov, A. I., Volkov, V. A., Novitskii, P. V. et. al.; Osadchii, E. P. (Ed.) (1979). Proektirovanie datchikov dlia izmereniia mekhanicheskikh velichin. Moscow: Mashinostroenie, 480.

6. Golovnin, V. A., Kaplunov, I. A., Malyshkina, O. V., Pedko, B. B., Movchikova, A. A.; Golovnin, V. A. (Ed.) (2016). Fizicheskie osnovy, metody issledovaniia i prakticheskoe primenenie pezomaterialoz. Moscow: Tekhnosfera, 272.

7. Ash, Zh. et. al. (1992). Datchiki izmeritelnykh sistem. Book 1. Moscow: Mir, 480

8. Kim, D. (2003). Teoriia avtomatieskogo upravleniia. Vol. 1. Lineinye sistemy. Moscow: FIZMATLIT, 288.
9. Astrom, K. J., Wittenmark, B. (2011). Computer-Controlled Systems: Theory and Design. Corporation, 557.

10. Dorf, R. C., Bishop, R. H. (2016). Modern Control Systems Pearson Education Limited, 1032

Kvasnikov Volodymyr, Doctor of Technical Sciences, Honored Metrologist of Ukraine, Head of Department of Computerized Electrical Systems and Technologies, National Aviation University, Kyiv,Ukraine,e-mail:kvp@nau.edu.ua, ORCID: https://orcid.org/ 0000-0002-7799-0001

Perederko Anatolij, PhD, Department of Metrology and Metrological Support, Odessa State Academy of Technical Regulation and Quality,Ukraine,e-mail: pal88@ukr.net, ORCID: https://orcid.org/ 0000-0002-9625-4798

UDC 614.841:536.46

DOI: 10.15587/2312-8372.2020.199252

\section{Dibrova 0., Kyrychenko O., Motrychuk R., Tomenko M., Melnyk V.}

\title{
FIRE SAFETY IMPROVEMENT OF PYROTECHNIC NITRATE-METAL MIXTURES UNDER EXTERNAL THERMAL CONDITIONS
}

Об’єктом дослідження є вплив співвідношення компонентів піротехнічних сумішей та тиску навколишнього середовища на температуру продуктів горіння та іх вміст у високотемпературному конденсаті. Дана тема є перспективною у зв'язку із тим, що останнім часом у світі все частіше застосовуються піротехнічні вироби різного призначення. Одним з найбільш проблемних місць є порушення правил пожежної безпеки під час їх зберігання, транспортування та застосування. У зазначених режимах відбувається передчасна їх експлуатачія, внаслідок чого утворюються високотемпературні конденсовані продукти згоряння. Дані речовини стікаються в різні сторони та становлять пожежну небезпеку для навколишніх об'єктів (будівель та споруд різного призначення, дерев'яних споруд об'єктів, лісових масивів, парків тощо).

В ході дослідження використовувалася база даних про температуру продуктів згоряння піротехнічних сумішей та їх вміст у високотемпературному конденсаті, які визначають їх властивості щодо пожежної небезпеки під час експлуатацї в умовах зовнішніх впливів. Дані, наведені у дослідженні, були отримані в результаті стандартних термодинамічних розрахунків і були зібрані за допомогою відомих методів множинної корелящії та регресї̈ у вигляді статистичних моделей.

За допомогою отриманих розрахунків встановлено істотний вплив співвідношення компонентів піротехнічних сумішей та тиску навколишнього середовища на температуру продуктів їх згоряння та їх вміст у високотемпературному конденсаті. Це дозволило визначити оптимальні діапазони параметрів зміни. Завдяки цьому забезпечується можливість отримання нових результатів. Для порівняння взято розрахунки з отриманими окремими експериментальними даними, для яких використовували вольфрамоворенієві термопари зі спеціальними екранами для запобігання адгезії конденсованих продуктів та зонди для ïx відбору. Результати показали, що різниці між ними не перевищували 8-10\%.

Ключові слова: пожежна безпека, піротехнічні суміші, нітратно-металеві суміші, термічна дія, піротехнічні вироби, термодинамічні розрахунки.

Received date: 12.11.2019

Accepted date: 11.12.2019

Published date: 28.02 .2020
Copyright (C) 2020, Dibrova O., Kyrychenko O., Motrychuk R., Tomenko M., Melnyk V. This is an open access article under the CC BY license (http://creativecommons.org/licenses/by/4.0)

\section{Introduction}

Nowadays, pyrotechnic mixtures of metallic fuels (aluminum, magnesium, titanium, zirconium, aluminum-magnesium alloys, etc.) are widely used in various fields. They are used in the national economy and military technology (mixtures for fireworks, lighting and signaling devices, elements of rocket and space technology, etc.) [1-3]. These mixtures 
include oxidizers that include nitrates (sodium, potassium, strontium, barium nitrates, etc.). As a result of premature burning of mixtures under external thermal influences (for example, during fires in storage, war zones, etc.), combustion products with high temperatures (up to 4000-4500 K) produce thermal condensate (up to $0.7-0.8$ relative content of products combustion). According to numerous field tests, this leads to fire and explosion burns of surrounding objects (buildings and structures of various purposes, timber structures, forests, parks, etc.) [4-6].

Therefore, when designing these products, it is necessary to control the temperature level of the mixture combustion products, as well as the content of high-temperature condensate in them. This will prevent the occurrence of fire hazard situations during storage and transportation of products [7].

High burning temperatures of pyrotechnic mixtures and their chemical activity make it difficult to directly measure the above characteristics. Therefore, to determine the possible ranges of temperature variation and content of mixture combustion condensed products, methods of thermodynamic analysis are widely used [8-10].

At the moment, data on the technological parameters influence patterns (excess coefficient of the oxidizing agent in the mixture $\alpha$ ) and external conditions (increased pressures of the environment, its composition, etc.) on the temperature and composition of the mixture combustion products are limited.

Therefore, it is relevant to study the effect of the ratio of the components of the pyrotechnic mixtures and the pressure of the environment on the temperature of their products of combustion and their content in high-temperature condensate, which allows to determine the optimal ranges of parameters of change.

Thus, the object of research is the effect of the ratio of the components of the pyrotechnic mixtures and the pressure of the environment on the temperature of the products of combustion and their content in high-temperature condensate.

The aim of this research is to determine the dependences of the combustion product temperature and the content of high-temperature condensate. In them for mixtures of aluminum powders with nitrate-containing oxidizing agents (sodium, potassium, strontium, and barium nitrates) using the methods of thermodynamic analysis.

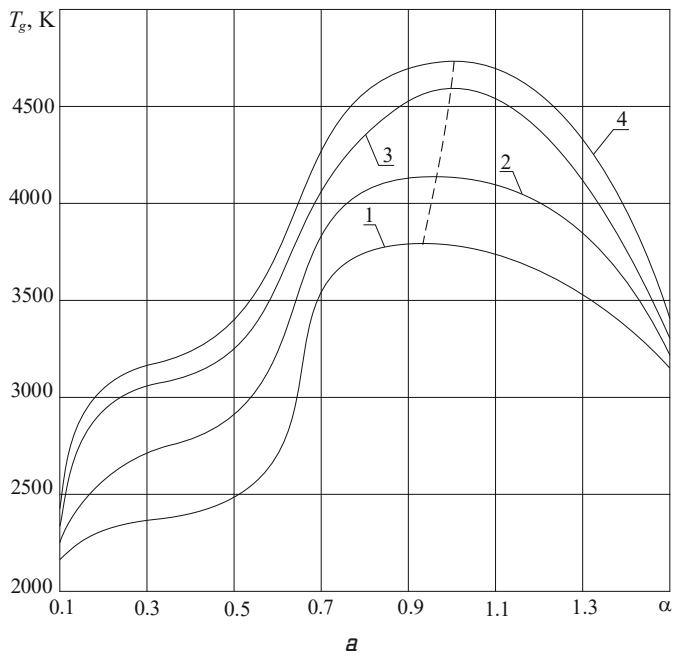

\section{Methods of research}

Thermodynamic calculations of the temperature and composition of the mixture combustion products were carried out at pressures from $10^{5} \mathrm{~Pa}$ to $10^{7} \mathrm{~Pa}$ and oxidizing agent excess coefficient $\alpha=0.15-0.55\left(\alpha_{v m g}=0.15-0.25-\right.$ value of the burning upper concentration limit, $\alpha_{n m g}=1.5-1.55-$ value of the burning lower concentration limit).

\section{Research results and discussion}

According to the calculations, the temperature of the nitrate-aluminum mixture combustion products substantially depends on the mixture ratio and pressure and has a maximum $T_{\text {gmax }}=3530-5050 \mathrm{~K}$, which lies in the range $\alpha=\alpha_{T_{g \max }}=0.87-1.04$ (Fig. 1-4). An increase in pressure from $10^{5} \mathrm{~Pa}$ to $10^{7} \mathrm{~Pa}$ irrespective of $\alpha$ leads to an increase of $T_{\text {gmax }}$ : for $\mathrm{Al}+\mathrm{NaNO}_{3}$ mixture - from $3770 \mathrm{~K}$ to $4760 \mathrm{~K}$; for $\mathrm{Al}+\mathrm{KNO}_{3}$ mixture - from $3530 \mathrm{~K}$ to $4570 \mathrm{~K}$; for $\mathrm{Al}+\mathrm{Sr}\left(\mathrm{NO}_{3}\right)_{2}$ mixture - from $3890 \mathrm{~K}$ to $5060 \mathrm{~K}$; for $\mathrm{Al}+\mathrm{Ba}\left(\mathrm{NO}_{3}\right)_{2}$ mixture - from $3630 \mathrm{~K}$ to $4870 \mathrm{~K}$. Herewith, the temperature of the mixture combustion products on the upper $\left(\alpha_{v m g}=0.25\right)$ and lower $\left(\alpha_{n m g}=1.55\right)$ burning concentration limits with a change in pressure from $10^{5} \mathrm{~Pa}$ to $10^{7} \mathrm{~Pa}$ changes:

- for $\mathrm{Al}+\mathrm{NaNO}_{3}$ mixture - from $2030 \mathrm{~K}$ to $2440 \mathrm{~K}$ and from $3060 \mathrm{~K}$ to $3480 \mathrm{~K}$;

- for $\mathrm{Al}+\mathrm{KNO}_{3}$ mixture - from $2030 \mathrm{~K}$ to $2230 \mathrm{~K}$ and from $2890 \mathrm{~K}$ to $3430 \mathrm{~K}$;

- for $\mathrm{Al}+\mathrm{Sr}\left(\mathrm{NO}_{3}\right)_{2}$ mixture - from $2290 \mathrm{~K}$ to $2630 \mathrm{~K}$ and from $3540 \mathrm{~K}$ to $3950 \mathrm{~K}$;

- for $\mathrm{Al}+\mathrm{Ba}\left(\mathrm{NO}_{3}\right)_{2}$ mixture - from $2070 \mathrm{~K}$ to $2560 \mathrm{~K}$ and from $3570 \mathrm{~K}$ to $3650 \mathrm{~K}$.

It has been established that for the mixtures under consideration as with an excess of metallic fuel $(\alpha<1)$, so with an excess of oxidizing agent $(\alpha>1)$ pressure increase leads to increased dependence $T_{g}(\alpha)$. Herewith the pressure influence at $\alpha<1$ are noticeably weaken for $\mathrm{Al}+\mathrm{Sr}\left(\mathrm{NO}_{3}\right)_{2}$ and $\mathrm{Al}+\mathrm{Ba}\left(\mathrm{NO}_{3}\right)_{2}$ mixtures. As for the effect of the oxidizing agent nature on the nature of the dependence $T_{g}(\alpha)$ for different pressures (Fig. 5), as for $\alpha<1$, so for $\alpha>1$ with increasing pressure, the effect of the oxidizing agent nature changes significantly.

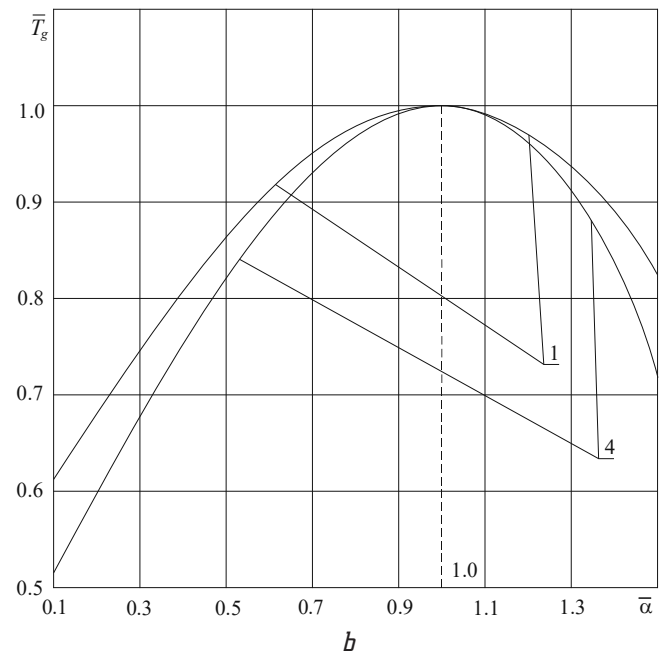

Fig. 1. The temperature dependence of the combustion products of the $\mathrm{Al}+\mathrm{NaNO}_{3}$ mixture on the coefficient of oxidant excess and external pressure: $a$ - the temperature of combustion products $T_{g}(\alpha, P) ; b$ - dimensionless temperature of combustion products $\bar{T}_{g}\left(\bar{\alpha}_{,} P\right)\left(\bar{T}_{g}=T_{g} / T_{g \max } ; \bar{\alpha}=\alpha / \alpha_{T_{g}=T_{g \max }}\right)$; $1-P=10^{5} \mathrm{~Pa}, 2-P=10^{6} \mathrm{~Pa}, 3-P=5 \cdot 10^{6} \mathrm{~Pa}, 4-P=10^{7} \mathrm{~Pa}$ 

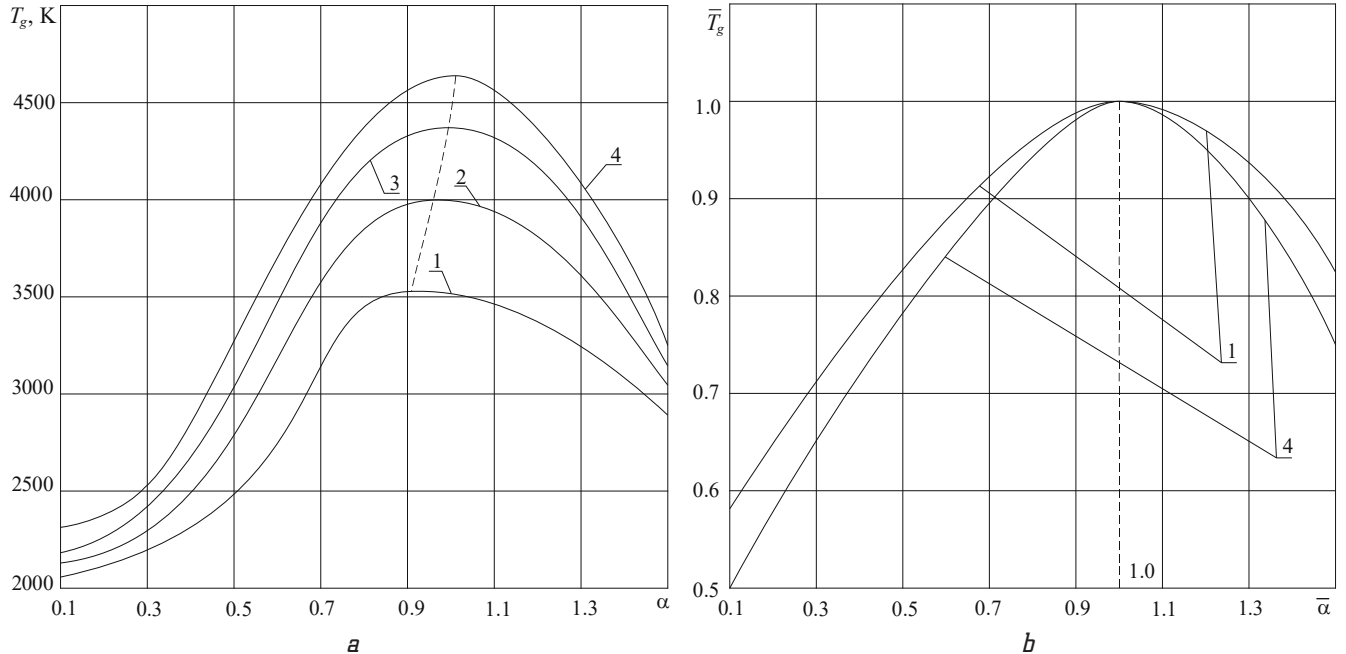

Fig. 2. The temperature dependence of the combustion products of the $\mathrm{Al}+\mathrm{KNO}_{3}$ mixture on the coefficient of excess oxidizer and external pressure: a - temperature of combustion products $T_{g}(\alpha, P) ; b$ - dimensionless temperature of combustion products $\bar{T}_{g}(\bar{\alpha}, P)$; $1-P=10^{5} \mathrm{~Pa}, 2-P=10^{6} \mathrm{~Pa}, 3-P=5 \cdot 10^{6} \mathrm{~Pa}, 4-P=10^{7} \mathrm{~Pa}$
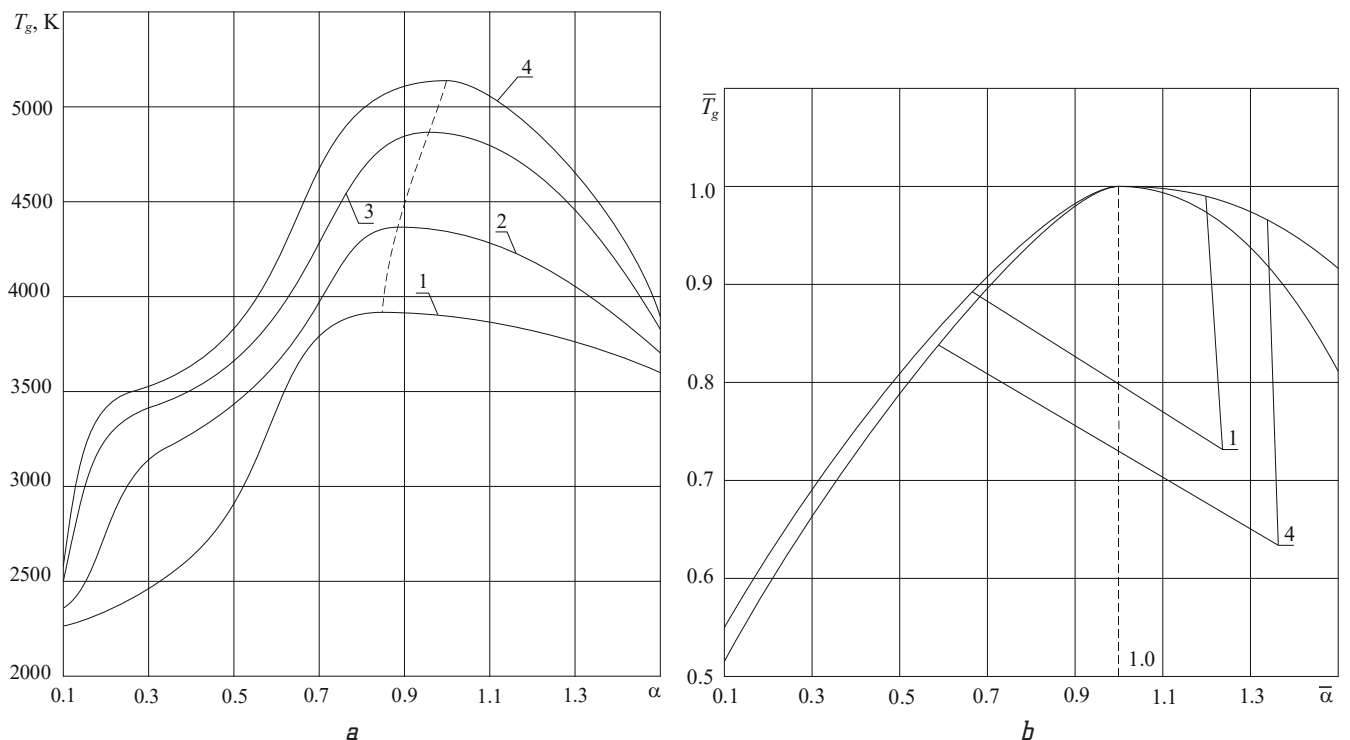

Fig. 3. The temperature dependence of the combustion products of the $\mathrm{Al}+\mathrm{S} r\left(\mathrm{NO}_{3}\right)_{2}$ mixture on the coefficient of axidant excess and external pressure: $a$ - temperature of combustion products $T_{g}(\alpha, P) ; b$ - dimensionless temperature of combustion products $\bar{T}_{g}\left(\bar{\alpha}_{,} P\right)$; $1-P=10^{5} \mathrm{~Pa}, 2-P=10^{6} \mathrm{~Pa}, 3-P=5 \cdot 10^{6} \mathrm{~Pa}, 4-P=10^{7} \mathrm{~Pa}$
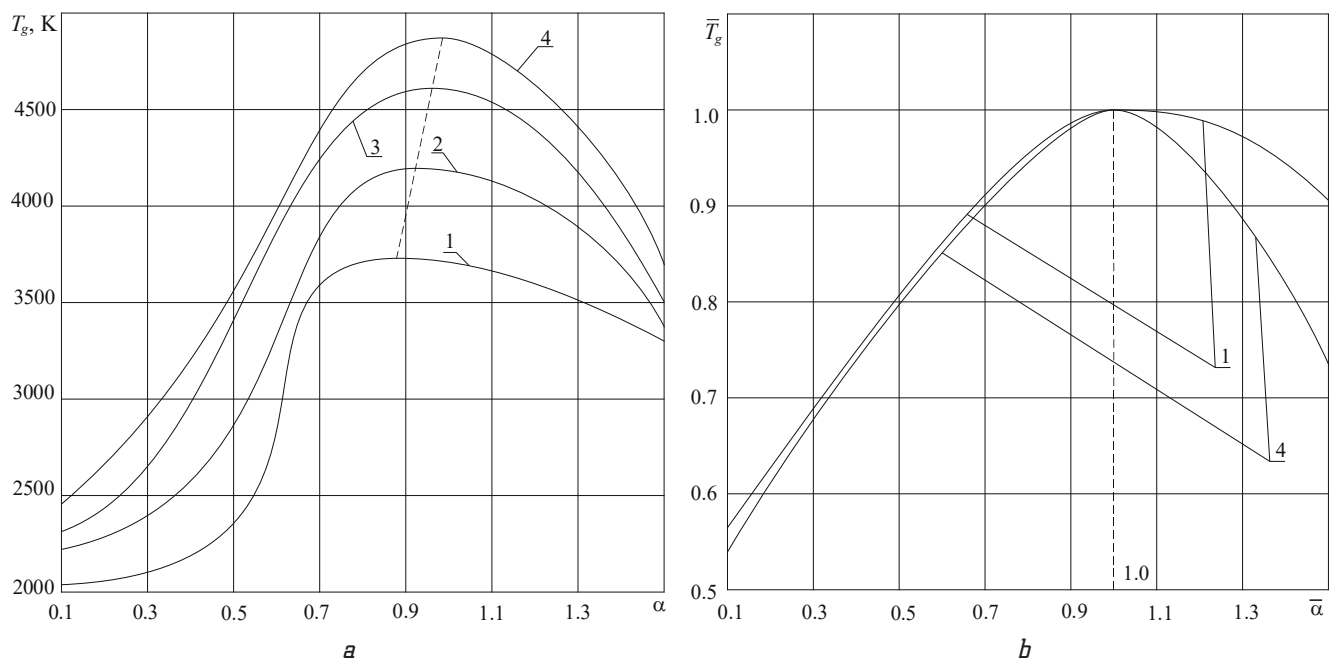

Fig. 4. The temperature dependence of the combustion products of the $\mathrm{Al}+\mathrm{Ba}\left(\mathrm{NO}_{3}\right)_{2}$ mixture on the coefficient of oxidant excess and external pressure: $a$ - temperature of combustion products $T_{g}(\alpha, P) ; b$ - dimensionless temperature of combustion products $\bar{T}_{g}(\bar{\alpha}, P)$; $1-P=10^{5} \mathrm{~Pa}, 2-P=10^{6} \mathrm{~Pa}, 3-P=5 \cdot 10^{6} \mathrm{~Pa}, 4-P=10^{7} \mathrm{~Pa}$ 


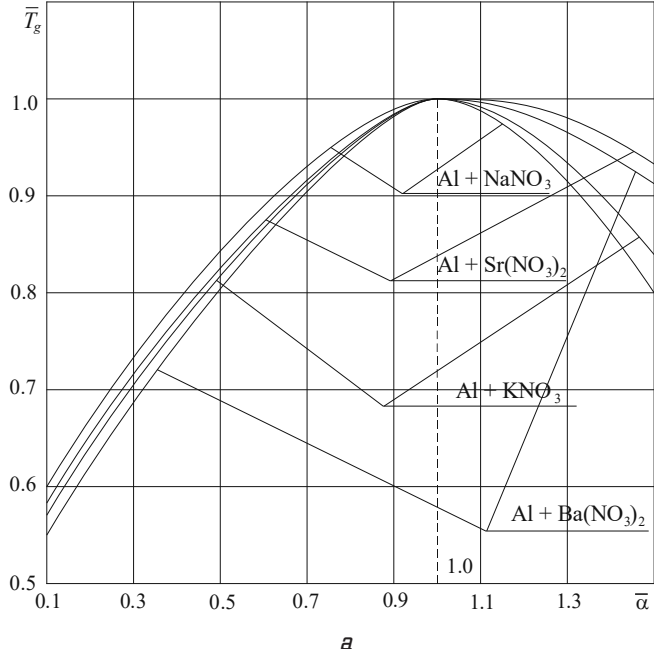

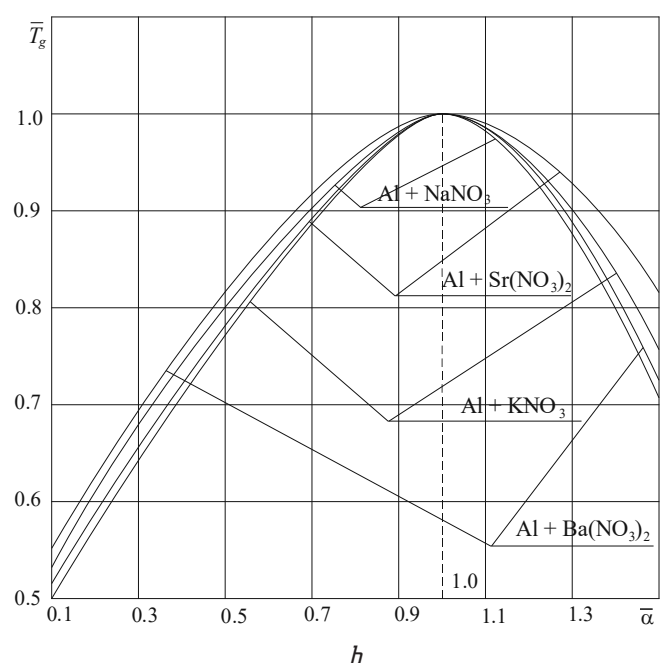

Fig. 5. Dependence of dimensionless temperature combustion mixture $\bar{T}_{g}(\bar{\alpha})$ for different external pressures: $a-P=10^{5} \mathrm{~Pa} ; b-P=10^{7} \mathrm{~Pa}$

For example, for $P=10^{5} \mathrm{~Pa}$ at $\alpha<1$ according to the degree of the oxidizing agent nature influence, the mixtures are arranged in the following row:

$$
\mathrm{Al}+\mathrm{Ba}\left(\mathrm{NO}_{3}\right)_{2}>\mathrm{Al}+\mathrm{KNO}_{3}>\mathrm{Al}+\mathrm{Sr}\left(\mathrm{NO}_{3}\right)_{2}>\mathrm{Al}+\mathrm{NaNO}_{3}
$$

and at $\alpha>1-$ in the row:

$$
\begin{aligned}
& \mathrm{Al}+\mathrm{NaNO}_{3}>\mathrm{Al}+\mathrm{KNO}_{3}>\mathrm{Al}+\mathrm{Ba}\left(\mathrm{NO}_{3}\right)_{2}> \\
& >\mathrm{Al}+\mathrm{Sr}\left(\mathrm{NO}_{3}\right)_{2}
\end{aligned}
$$

for $P=10^{7} \mathrm{~Pa}$ at $\alpha<1-$ in the row:

$$
\begin{aligned}
& \mathrm{Al}+\mathrm{KNO}_{3}>\mathrm{Al}+\mathrm{Sr}\left(\mathrm{NO}_{3}\right)_{2}>\mathrm{Al}+\mathrm{NaNO}_{3}> \\
& >\mathrm{Al}+\mathrm{Ba}\left(\mathrm{NO}_{3}\right)_{2},
\end{aligned}
$$

and for $\alpha>1$ - in the row:

$$
\begin{aligned}
& \mathrm{Al}+\mathrm{NaNO}_{3}>\mathrm{Al}+\mathrm{Ba}\left(\mathrm{NO}_{3}\right)_{2}>\mathrm{Al}+\mathrm{KNO}_{3}> \\
& >\mathrm{Al}+\mathrm{Sr}\left(\mathrm{NO}_{3}\right)_{2} .
\end{aligned}
$$

The comparative analysis of dependencies $T_{g}(P)$ (Fig. 6, 7) for the equivalence ratio in mixtures near the upper $\left(\alpha_{v m g}=\right.$ $=0.25)$ and lower $\left(\alpha_{n m g}=1.55\right)$ concentration limits of burning shows, near the upper limit of the burning concentration according to the degree of dependence enhancement $T_{g}(P)$ mixtures are arranged in the row:

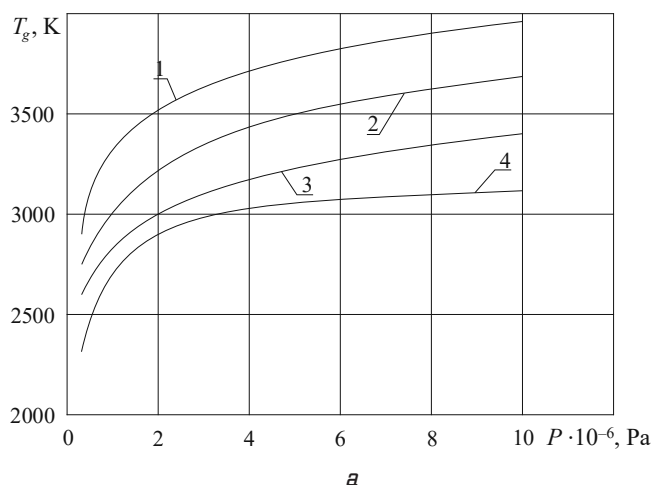

$$
\begin{aligned}
& \mathrm{Al}+\mathrm{Ba}\left(\mathrm{NO}_{3}\right)_{2}<\mathrm{Al}+\mathrm{Sr}\left(\mathrm{NO}_{3}\right)_{2}<\mathrm{Al}+\mathrm{NaNO}_{3}< \\
& <\mathrm{Al}+\mathrm{KNO}_{3},
\end{aligned}
$$

and near the lower limit of the burning concentration - in the row:

$$
\begin{aligned}
& \mathrm{Al}+\mathrm{NaNO}_{3}<\mathrm{Al}+\mathrm{Ba}\left(\mathrm{NO}_{3}\right)_{2}<\mathrm{Al}+\mathrm{Sr}\left(\mathrm{NO}_{3}\right)_{2}< \\
& <\mathrm{Al}+\mathrm{KNO}_{3} .
\end{aligned}
$$

According to the calculations, the relative content of high-temperature condensate $g_{K}$ in the combustion products of the mixtures under consideration substantially depends on the external pressure (Fig. 8, $a$ ): when $P$ increases from $10^{5} \mathrm{~Pa}$ to $10^{7} \mathrm{~Pa}$, the value $g_{K}$ increases in $1.8-2.3$ times. In addition, according to the degree of dependence enhancement $g_{K}(P)$ mixtures are arranged in the row (Fig. 8, $b$ ):

$$
\begin{aligned}
& \mathrm{Al}+\mathrm{NaNO}_{3}<\mathrm{Al}+\mathrm{KNO}_{3}<\mathrm{Al}+\mathrm{Ba}\left(\mathrm{NO}_{3}\right)_{2}< \\
& <\mathrm{Al}+\mathrm{Sr}\left(\mathrm{NO}_{3}\right)_{2} .
\end{aligned}
$$

A change in the equivalence ratio in the mixture both toward the excess of metallic fuel and towards the excess of oxidizing agent also significantly affects the nature of the dependence $g_{K}(P)$ regardless of the nature of the oxidizing agent. For example, for a mixture of aluminum with sodium nitrate, an increase in $\alpha$ from 0.25 to 1.55 leads to a significant weakening of the dependence $g_{K}(P)$ in 2-2.5 times (Fig. 9).

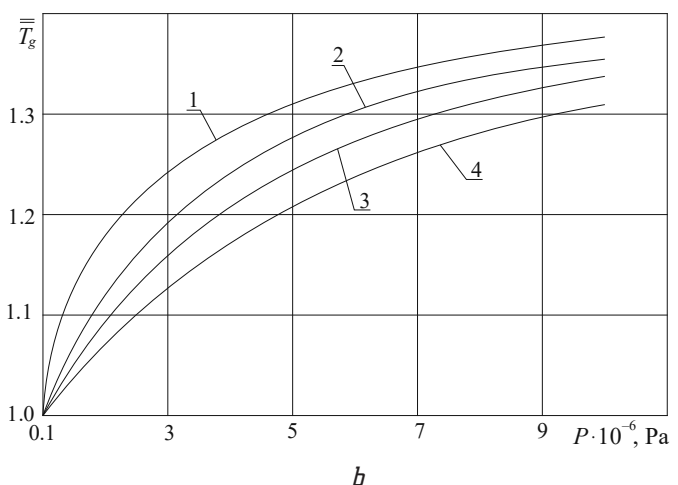

Fig. 6. Temperature dependences of combustion products of mixtures and their relative values $\overline{\bar{T}}_{g}\left(\overline{\bar{T}}_{g}=T_{g} /\left(T_{g}\right)_{P=10^{5}}\right)$ on the external pressure near the upper concentration limit of combustion $(\alpha=0.5)$ : a - $1-\mathrm{Al}+\mathrm{Sr}\left(\mathrm{NO}_{3}\right)_{2}, 2-\mathrm{Al}+\mathrm{Ba}\left(\mathrm{NO}_{3}\right)_{2}, 3-\mathrm{Al}+\mathrm{NaNO} \mathrm{N}_{3}, 4-\mathrm{Al}+\mathrm{KNO}_{3}$; $b-1-\mathrm{Al}_{+} \mathrm{KNO}_{3}, 2-\mathrm{Al}+\mathrm{NaNO}_{3}, 3-\mathrm{Al}+\mathrm{5r}\left(\mathrm{NO}_{3}\right)_{2}, 4-\mathrm{Al}+\mathrm{Ba}\left(\mathrm{NO}_{3}\right)_{2}$ 

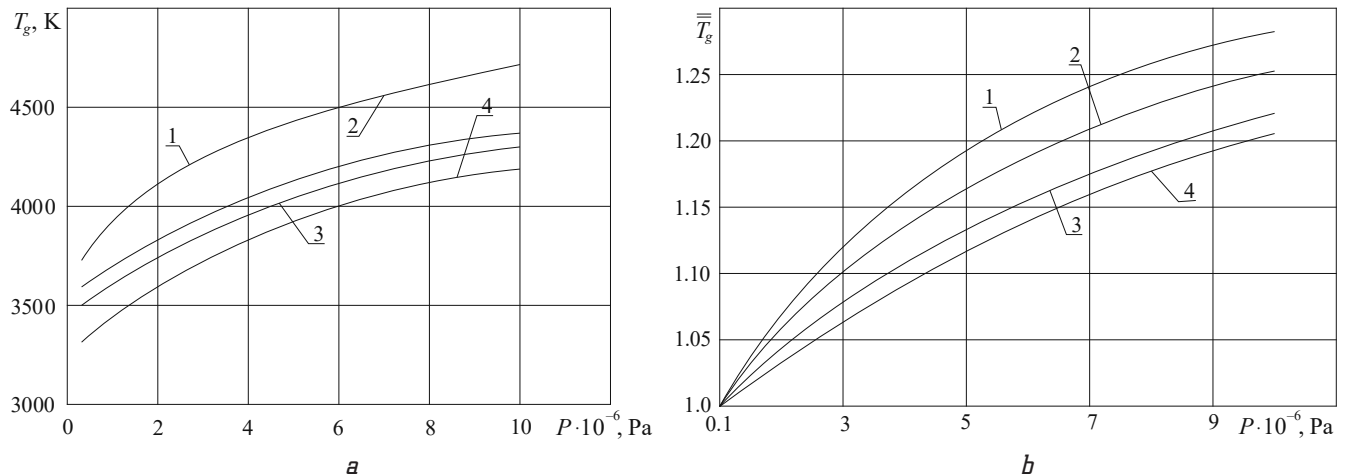

Fig. 7. The temperature dependence of the combustion products of the mixtures and its relative values on the external pressure near the lower concentration limit of combustion $(\alpha=1.3): a-1-\mathrm{Al}+\mathrm{Sr}\left(\mathrm{NO}_{3}\right)_{2}, 2-\mathrm{Al}+\mathrm{NaNO}_{3}, 3-\mathrm{Al}+\mathrm{Ba}\left(\mathrm{NO}_{3}\right)_{2}, 4-\mathrm{Al}+\mathrm{KNO}_{3}$ $b-1-\mathrm{Al}+\mathrm{KNO}_{3}, 2-\mathrm{Al}+\mathrm{Sr}\left(\mathrm{NO}_{3}\right)_{2}, 3-\mathrm{Al}+\mathrm{Ba}\left(\mathrm{NO}_{3}\right)_{2}, 4-\mathrm{Al}+\mathrm{NaNO}_{3}$
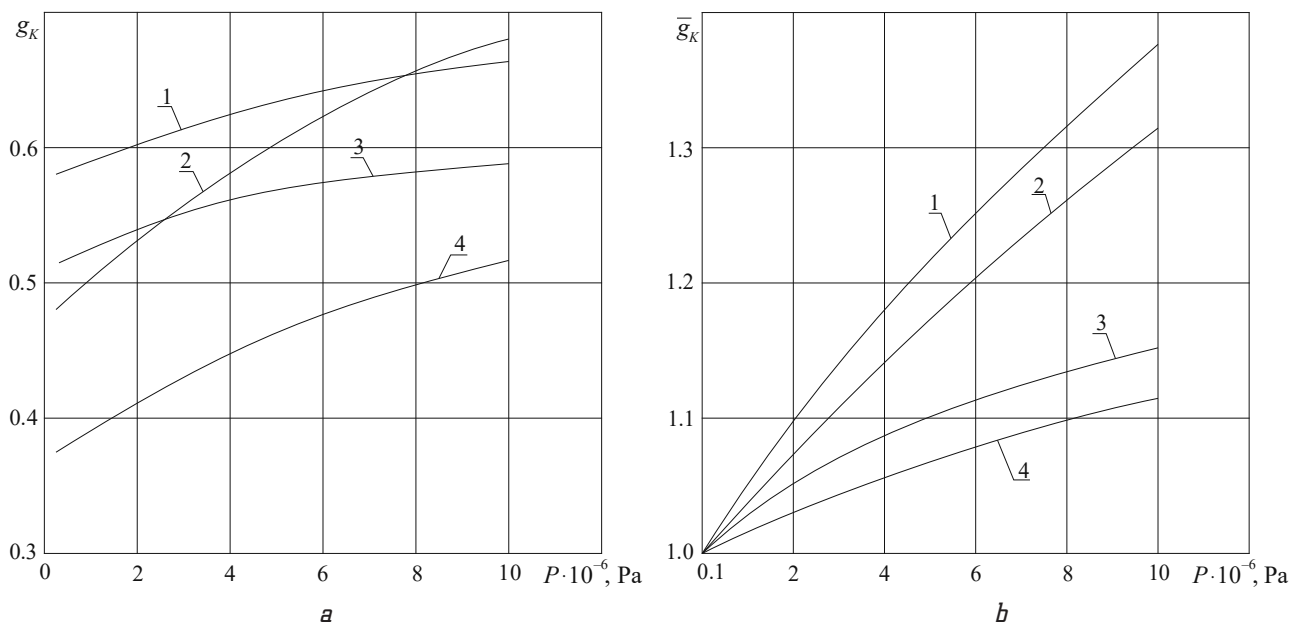

Fig. 8. Dependences of the relative mass content of high-temperature condensate in the combustion products of the mixture from the external pressure $(\alpha=1.0): a-g_{K \prime}, 1-\mathrm{Al}+\mathrm{NaNO}_{3}, 2-\mathrm{Al}+\mathrm{Sr}\left(\mathrm{NO}_{3}\right)_{2}, 3-\mathrm{Al}+\mathrm{KNO}_{3}, 4-\mathrm{Al}+\mathrm{Ba}\left(\mathrm{NO}_{3}\right)_{2}$; $b-\bar{g}_{K}, 1-\mathrm{Al}+\mathrm{Sr}_{\mathrm{r}}\left(\mathrm{NO}_{3}\right)_{2}, 2-\mathrm{Al}+\mathrm{Ba}\left(\mathrm{NO}_{3}\right)_{2}, 3-\mathrm{Al}+\mathrm{KNO}_{3}, 4-\mathrm{Al}+\mathrm{NaNO}$
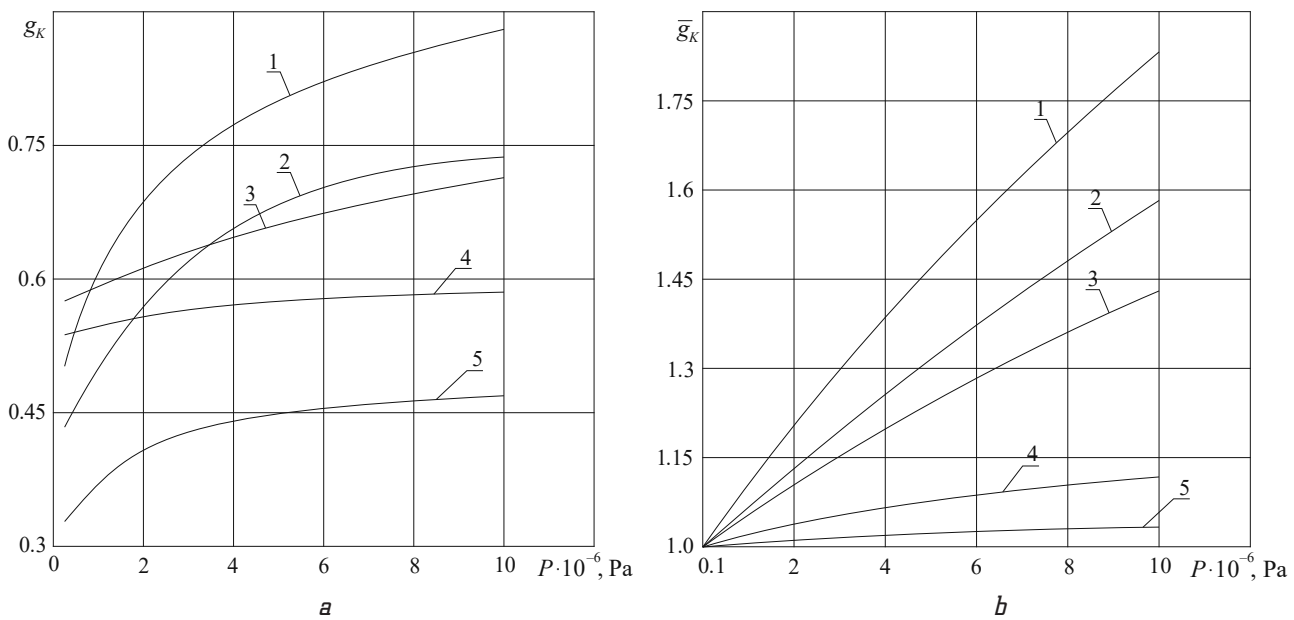

Fig. 9. Dependences related to the mass content of high-temperature condensate in the combustion products of the $\mathrm{Al}^{+\mathrm{NaNO}} \mathrm{N}_{3}$ mixture on the external pressure for different values of the oxidant excess coefficient: $a-9 K_{1}, 1-\alpha=0.2,2-\alpha=0.3,3-\alpha=1.0,4-\alpha=1.5,5-\alpha=0.5$; $b-\bar{g}_{K}, 1-\alpha=0.2,2-\alpha=0.3,3-\alpha=0.5,4-\alpha=1.0,5-\alpha=1.5$

It is established that the temperature of combustion products of nitrate-aluminum mixtures is significantly dependent on the ratio of components and pressure and has maximum values $3530-5050 \mathrm{~K}$, when $\alpha=0.87-1.04$. While increasing the pressure from $10^{5} \mathrm{~Pa}$ to $10^{7} \mathrm{~Pa}$ causes the specified temperature to increase by 1.1-1.3 times.

It is shown that both with excess metal fuel $(\alpha<1)$, and with the excess oxidant $(\alpha>1)$ increasing the pres- sure leads to an increase in the temperature dependence of the combustion products of the mixtures on the ratio of components, regardless of the nature of the oxidizer.

It is established that the relative content of hightemperature condensate in the products of combustion of mixtures increases by $1.8-2.3$ times with increasing external pressure from $10^{5} \mathrm{~Pa}$ to $10^{7} \mathrm{~Pa}$. 
It is shown that the change in the ratio of the components in the mixture, regardless of the nature of the oxidizer, substantially affects the nature of the dependence of the relative content of high-temperature condensate in the combustion products from the external pressure. Increasing the oxidizer content of the $\mathrm{Al}+\mathrm{NaNO}_{3}$ mixture from $\alpha=0.25$ to $\alpha=1.55$ leads to a decrease in the specified dependency by $2-2.5$ times.

\section{Conclusions}

In the course of the study the influence of the ratio of the components of pyrotechnic mixtures and the pressure of the environment on the temperature of their products of combustion and their content in high-temperature condensate was determined - magnesium alloys, the so-called pyrotechnic nitrate-metal mixtures. Thanks to the work done, it is possible to obtain results. These findings were compared with the results of calculations with the results of separate experimental data, which used tungsten-rhenium thermocouples with special screens to prevent adhesion of condensed products and probes. Their selection showed that the difference between them was not $8-10 \%$. This ensures new results. For comparison, calculations were made with separate experimental data for which tungstenrhenium thermocouples with special screens were used to prevent the adhesion of condensed products and probes for their selection. The results showed that the differences between them did not exceed 8-10\%.

\section{References}

1. Li, W., Min, S., Wang, F., Zhang, Z. (2020). Layered metallic vanadium diboride as an active cocatalyst for efficient dye-sensitized photocatalytic hydrogen evolution. Sustainable Energy \& Fuels, 4 (1), 116-120. doi: http://doi.org/10.1039/c9se00820a

2. Liu, S., Guo, Z., Qian, X., Zhang, J., Liu, J., Lin, J. (2019). Sonochemical deposition of ultrafine metallic Pt nanoparticles on CdS for efficient photocatalytic hydrogen evolution. Sustainable Energy \& Fuels, 3 (4), 1048-1054. doi: http://doi.org/ $10.1039 / \mathrm{c} 9 \mathrm{se} 00050 \mathrm{j}$

3. Harries, M. E., Huber, M. L., Bruno, T. J. (2019). A Distillation Approach to Phase Equilibrium Measurements of Multicomponent Fluid Mixtures. Energy \& Fuels, 33 (8), 7908-7915. doi: http://doi.org/10.1021/acs.energyfuels.9b01366

4. Vashhenko, V. A., Kirichenko, O. V., Lega, Iu. G., Zaika, P. I., Iatsenko, I. V., Tsybulin, V. V. (2008). Protsessy goreniia metallizirovannykh kondensirovannykh sistem. Kyiv: Naukova dumka, 745.
5. Kyrychenko, O. V., Akinshyn, V. D., Vashchenko, V. A., Tsybulin, V. V. (2011). Termodynamichni metody prohnozuvannia pozhezhonebezpechnykh vlastyvostei vysokometalizovanykh pirotekhnichnykh nitratno-metalichnykh sumishei v umovakh zovnishnikh termovplyviv. Problemi pozharnoi bezopasnosty, 30, 104-106.

6. Kyrychenko, O. V., Pashkovskyi, P. S., Vashchenko, V. A., Leha, Yu. H. (2012). Osnovy pozhezhnoi bezpeky pirotekhnichnykh nitratoomisnykh vyrobiv pid zovnishnimy termichnymy vplyvamy. Kyiv: Naukova dumka, 318.

7. Shidlovskii, A. A. (1973). Osnovy pirotekhniki. Moscow: Mashinostroenie, 320 .

8. Kirillov, G. N., Deshevykh, Iu. I., Giletich, A. N., Vogman, L. P., Zuikov, V. A., Nestrugin, A. N., Pshenichnikov, A. M. (2010) Trebovaniia pozharnoi bezopasnosti pri obrashhenii pirotekhnicheskoi produktsii. Obzorno-analiticheskii material. Moscow: VNIIPO i DND MCHS Rossii, 19.

9. Silin, N. A., Vashhenko, V. A., Kashporov, L. Ia. et. al. (1976). Metallicheskie goriuchie geterogennykh kondensirovannykh sistem. Moscow: Mashinostroenie, 320.

10. Vogman, L. P., Zuikov, V. A., Tatarov, V. E., Lepesii, V. V. (2002). Razrabotka rekomendatsii po obespecheniiu pozharnoi bezopasnosti feierverochnykh pirotekhnicheskikh izdelii. Pozharovzryvobezopasnost, 3, 24-41.

Dibrova Oleksiy, Adjunct, National University of Civil Defence of Ukraine, Kharkiv, Ukraine, e-mail: okskir@meta.ua, ORCID: https:// orcid.org/0000-0002-4496-2178

Kyrychenko Oksana, Doctor of Technical Sciences, Professor, Head of Department of Fire Prevention Work, Cherkasy Institute of Fire Safety named after Chornobyl Heroes of National University of Civil Defense of Ukraine, Ukraine,e-mail: okskir@meta.ua, ORCID: https:// orcid.org/0000-0002-0240-1807

Motrichuk Roman, Adjunct, Department of the State Emergency Service of Ukraine in the Cherkasy Region, Ukraine, e-mail: r_motrichuk@ukr.net, ORCID: https://orcid.org/0000-0002-5670-6788

Tomenko Marina, PhD, Associate Professor, Department of Fire Prevention Work, Cherkasy Institute of Fire Safety named after Chornobyl Heroes of National University of Civil Defense of Ukraine, Ukraine, e-mail:marina_tomenko@ukr.net, ORCID: https://orcid.org/ 0000-0002-2354-9106

Melnyk Valentin, PhD, Head of Faculty, Faculty of Fire Safety, Cherkasy Institute of Fire Safety named after Chornobyl Heroes of National University of Civil Defense of Ukraine, Ukraine, e-mail: poiskoviksy@yahoo.com, ORCID: https://orcid.org/00000001-6593-5964 